In the original published article, country names were missing from the author affiliations. This has now been corrected. services: NHS examples of real-time practice in times of normal and pandemic healthcare delivery. BJPsych Bull 2020; 44(6): 277-84. Available from: https://doi.org/10.1192/bjb.2020.71

\title{
Reference
}

Johns G, Tan J, Burhouse A, Ogonovsky M, Rees C and Ahuja A. A visual step-by-step guide for clinicians to use video consultations in mental health

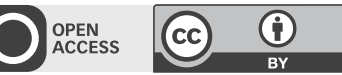

\section{Supporting people in mental health crisis in 21st-century Britain - ERRATUM}

Andrew Molodynski, Stephen Puntis, Em Mcallister, Hannah Wheeler, Keith Cooper

BJPsych Bulletin (2022) 46, 193-193, doi:10.1192/bjb.2020.143

(c) The Authors 2020. This is an Open Access article, distributed under the terms of the Creative Commons Attribution licence (http://creativecommons.org/ licenses/by/4.0/), which permits unrestricted re-use, distribution, and reproduction in any medium, provided the original work is properly cited.

https://doi.org/10.1192/bjb.2019.93, Published online by the Royal College of Psychiatrists, 22 January 2020

In the original published article, country names were missing from the author affiliations. This has now been corrected.

\section{Reference}

Molodynski A, Puntis S, McAllister E, Wheeler H and Cooper K. Supporting people in mental health crisis in 21st-century Britain. BJPsych Bull 2020; 44 (6): 231-32. Available from: https://doi.org/10.1192/bjb.2019.93.

\section{A model for specific goals for in-patient treatment linked to resources and limitations in out-patient treatment - ERRATUM}

Virginia Davies

BJPsych Bulletin (2022) 46, 193-194, doi:10.1192/bjb.2020.142

(c) The Author(s), 2020. This is an Open Access article, distributed under the terms of the Creative Commons Attribution licence (http://creativecommons.org/ licenses/by/4.0/), which permits unrestricted re-use, distribution, and reproduction in any medium, provided the original work is properly cited. 